\title{
SAMA pitches in to help victims of adverse medical events
}

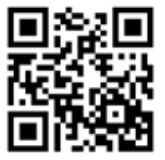

The South African Medical Association (SAMA) is investigating setting up a fund to compensate patients who fall victim to unavoidable adverse events (through no fault of their treating physician), while working with government to improve the overall quality of care in both the public and private sectors.

\section{Another legal 'driver' was the 1997 Contingency Fees Act, which permits attorneys to offer clients 'free' legal help in pursuing a suit against a medical practitioner (in fact $25 \%$ of the settlement or double their usual fee, whichever is the lesser).}

SAMA Chairperson Dr Mzukisi Grootboom emphasised that this would in no way affect legitimate medical negligence claims, but form part of an overall strategy to address a crisis that threatened the very existence of higher-risk specialist care in South Africa (SA) - something that would negatively impact on patients. Identifying and compassionately addressing genuinely unavoidable accidents and adverse outcomes, while teaching doctors to communicate openly and honestly with their patients, would help reduce the expensive rising tide of pending claims. SA, while seriously short of specialists, nevertheless had some of the best and most sought-after practitioners in the world, with ground-breaking and/or lifesaving procedures an almost everyday occurrence. He cited Dr Graham Howarth, Africa representative for the global Medical Protection Society (MPS), to which most doctors in South Africa belong, as recently saying that an extrapolation of the annual indemnity fee hikes necessary to counter rising claims over the next 5-10 years 'begs the question of whether anyone will be left in the private sector to deliver babies [for example] at all. Grootboom said that private obstetricians would this year pay the highest annual indemnity subscriptions at ZAR450 000 per annum, which came on top of their equipment, office and administration overheads. The 'very real danger' existed that this could induce them and other high-risk consultants to avoid certain procedures and/ or move to the public sector (where the state pays for their indemnity cover), which he described as 'simply shifting the problem elsewhere', hiking the taxpayer-footed legal bill, which could potentially cripple or at least severely curtail overall public healthcare delivery. The rising curve in MPS settlements involving local obstetricians graphically illustrates the problem; the payout in 2013 was ZAR13 million, up from ZAR2 million in 2003 (the latter involving a single claim).

\section{Claims out of kilter with negligence trends - SAMA}

Echoing what national health minister Dr Aaron Motsoaledi said in Gauteng at an early March medicolegal summit called to address the escalating crisis, Grootboom said that the local explosion in medicolegal claims was not in keeping with generally known trends of negligence. Recent amendments to the Road Accident Fund legislation made damages claims for personal injury sustained in motor vehicle accidents now a far less lucrative source of income for lawyers, who had shifted their target to doctors and hospitals. Another legal 'driver' was the 1997 Contingency Fees Act, which permits attorneys to offer clients 'free' legal help in pursuing a suit against a medical practitioner (in fact $25 \%$ of the settlement or double their usual fee, whichever is the lesser). Motsoaledi accused some (unnamed) chief health executives at his public hospitals of being in cahoots with lawyers to cash in on the lucrative litigation. 'They and others in the health sector are members of syndicates which have permeated our hospitals, sharing information which leads to the looting of funds meant for members of the public, he charged at the indemnity summit. Gauteng, KwaZulu-Natal and the Eastern Cape currently have claims against them worth billions; Gauteng alone faces medical negligence claims estimated at ZAR1.268 billion. The Black Lawyers Association (BLA) strongly attacked Motsoaledi’s 'fingerpointing, saying that he should be more introspective and examine the true cause of the massive lawsuits channelled against his department. It bemoaned SAMA's apparent support for the minister at the medicolegal summit, saying that it amounted to 'an orchestrated assault on the rights of the downtrodden and victims of malpractice in public healthcare' and that both the BLA and SAMA should campaign for higher professional standards among their members when treating members of the public.

\section{A 'no-fault' compensation} scheme has already been suggested by top health science academics in order to limit the costs of medical negligence and its impact on NHI. This would limit legal costs for provincial health departments and private practitioners by reducing the number of court cases.

\section{National Health}

\section{Insurance delivery under threat}

Over the past 13 years the overall indemnity insurance paid by private doctors to protect themselves against medical negligence claims has risen by $573 \%$, pushing up their fees and encouraging those not contemplating the financially safer haven of the state sector to look overseas for opportunities - or simply give up their practices. The annual MPS subscription for a private neurosurgeon in SA will this year reach ZAR338 520, while plastic, bariatric, orthopaedic, non-spinal and fertility surgeons will pay ZAR140 860 per annum. The greatest number of claims, with the highest damages paid, are in obstetrics, neurosurgery, spinal surgery, trauma and orthopaedics, all highly sought-after and understaffed disciplines with severe work pressure. Grootboom said it was entirely possible that newly qualified doctors would steer clear of such specialisation unless the situation was quickly mitigated or corrected, further undermining the government's ability to deliver universal healthcare via National Health Insurance (NHI). He said he was fully aware there were other drivers behind the rising litigation (such as diminished supervision of juniors, a lack of necessary nursing skills, equipment and drugs, and insufficient and thinly spread medical expertise, especially in more rural areas). However, by improving best practice skills and straightforward communication with patients, and working with government to diminish risk 
to patients, SAMA hoped that doctors could better live up to their dictum of, 'first do no harm' and avoid having to practise defensively in a hostile, pressurised and uncertain climate. A 'no-fault' compensation scheme has already been suggested by top health science academics in order to limit the costs of medical negligence and its impact on NHI. This would limit legal costs for provincial health departments and private practitioners by reducing the number of court cases. Such a system does not rule out court action for those dissatisfied with their compensation, but rather creates a short cut for patients who prefer not to go through protracted and expensive legal battles.

\section{Ubuntu approach vital for resolution}

Motsoaledi said at the medicolegal summit that unless something was done about the increasing rates of medical negligence claims, 'the whole system will suffer immeasurable damage'. He recently appointed an independent ombudsman to look into patient complaints, while the Office of Health Standards Compliance, tasked with setting and monitoring minimum standards for all hospitals (public and private) in advance of the $\mathrm{NHI}$, is also expected to have some impact on the crisis. Howarth of the
MPS commented in an article published recently in the $S A M J$ : 'I think it points to the kind of future we'd have if people are not very careful. Private patients, providers, public patients and providers, politicians and policy pundits all have a vested interest in solving the problem there is not a medical answer - it has to enter public debate.'

\section{Chris Bateman}

chrisb@hmpg.co.za

S Afr Med J 2015;105(5):337-338.

DOI:10.7196/SAMJ.9683 